\title{
Solving traffic congestion consequences regarding e-taxi parking by identifying a suitable location for the e-taxi station: geo-spatial and AHP approaches
}

\author{
Mazed Parvez
}

BURP, Urban and Regional Planning, Pabna University of Science and Technology, Pabna, Bangladesh and MURP, Urban and Regional Planning, Bangladesh University of Engineering and Technology, Dhaka, Bangladesh

\begin{abstract}
Purpose - The quantity of e-taxi in Bangladesh is increasing day by day, especially in the municipality area. With the increase of this e-taxi quantity, it becomes hard to provide parking space for these consequences the illegal parking on road. This parking consequences traffic congestion on the road and obstructs the free flow of traffic. So, this paper aims to investigate the present scenario of this e-taxi parking problem and provides a solution by finding out a suitable location for an e-taxi station by the analytic hierarchy process (AHP) approach.
\end{abstract}

Design/methodology/approach - For the study, both primary and secondary data were collected. Primary data on existing parking points on the road of e-taxi which consequences traffic congestion are collected from the Municipality area. Secondary data on the existing road network of the Pabna Municipality has collected from the MIDP data also from the literature review. For the suitability analysis process for establishing an e-taxi station, six variables were determined. These variables are determined from the previous studies and the expert opinion survey. The six variables are land use of the study area, road network of the study area, proximity to the office area, proximity to the educational facilities, proximity from the market and finally,proximity from the hospital. After the selection of the variables ranking value was determined from the expert opinion. Then using The AHP method final weight value is determined and, finally, with the assist of geographical information system.

Findings - From the resulting total 4,285 spots were found as optimally suitable spots are found which is almost $21 \%$ of the suitable spot. No mostly suitable spots are found from the GIS analysis. The moderately suitable spots were found in the prime number of 14,817 spots, almost $75 \%$ of the suitable spot. Likely the most suitable spots no partly suitable spots were found but the number of very few suitable spots was found in the number of $918,4 \%$ of the suitable spot. A total of 20,020 spots was found as suitable for the construction of E-taxistation.

Originality/value - Finding out a suitable spot for e-taxi stand the traffic congestion can be solved, accident risk can be minimized during loading and unloading of passengers and the municipality authority can find a permanent solution for the traffic congestion problem.

Keywords AHP, Traffic congestion, E-taxi, Level of service

Paper type Case study

(C) Mazed Parvez. Published in Smart and Resilient Transportation. Published by Emerald Publishing Limited. This article is published under the Creative Commons Attribution (CC BY 4.0) licence. Anyone may reproduce, distribute, translate and create derivative works of this article (for both commercial and noncommercial purposes), subject to full attribution to the original publication and authors. The full terms of this licence maybe seen at http://creativecommons.org/licences/by/4.0/legalcode

Geo-spatial and AHP approaches

Received 23 July 2020 Revised 17 September 2020 Accepted 17 September 2020
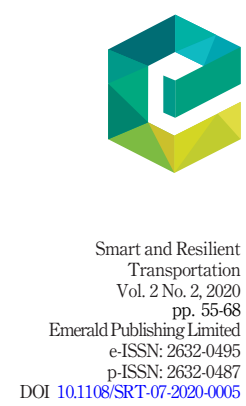
SRT

2,2

56

\section{Introduction}

Pabna is one of the ancient towns in Bangladesh. Therefore, masses of provider facilities were focused within the town. As a result, the populace of the town is growing daily. This expanded population generates several journeys inside the town street. But transport centers have now not been developed in contrast with the increased populace. As a result, site visitor congestion has emerged as a commonplace situation in the town. Residents must face woeful visitors jam every day even as traveling through the downtown roads of the city (Hossain and Hasan, 2019). Non-motorized automobiles (e.g. Rickshaws) and small size motor-powered vehicles (e.g. Car-rickshaws or e-taxi) are famous para-transit modes that supplied door-to-door carrier in congested parts of the metropolitan region (Rahman et al., 2004). That is why the taxi and e-taxi are one of the important neighborhood public transports. This visitor's mode has unique characteristics lacking in other public transport (e.g. public buses and railway) services (Fukumoto et al., 2017). Authority of the Pabna municipality formally assured that number of provided licenses up to 1200 e-taxi and 530 rickshaws and also state that almost the same o a greater number of unauthorized e-taxi have also existed at the municipality area (Chakma et al., 2018). As a result of the growing automobile population, towns regularly allow parking or brief parking in street segments without heavy traffic and light traffic (Cao et al., 2016). Besides the populace boom, the unplanned boom of shops, hospitals, and other industrial buildings results in the troubles of congestion and increases the demand for parking spaces (Banu and Rahman, 2016). Parking is one of the extreme issues that confront the city planner and traffic engineer. Earlier than any degree for the betterment of the conditions may be formulated fundamental statistics bearing on the provision of parking space (Subramani, 2012). Due to the on-avenue parking, a few war factors are created close to the undesignated parking areas in the Pabna Municipality area mainly in CBD. For incorrect distribution of parked automobiles at the undesignated spaces some struggle factors are located during the survey length. The prevailing study unearths that there are not any public parking facilities (Rahman et al., 2017). That is why it becomes urgent to establish a parking place for the automobiles. There is a bus stand, Central Terminal as well as CNG station at Pabna Municipality area. But there is not a single e-taxi parking zone or an auto stand at the area which consequences parking on the street for loading and unloading the passengers. This parking causes traffic congestion. So, it becomes a burning question to establish an e -taxi stand. For the establishment of an e-taxi stand, an appropriate and proper spot should be selected. Geographical Information System (GIS) is an instrument, which is effectively cast-off numerous times to support the policymakers in the choice of locations for any planned growth activity (Khahro et al., 2014). GIS acting an important part in preserving data and studying optimum sites. GIS is an instrument that diminishes the period and cost of the site selection and delivers a digital data bank for imminent monitoring sequencer of the designated places (Al-shabeeb, 2016). The analytic hierarchy process (AHP) has to turn out to be one of the most important up-to-date methods for suitability analysis via a geographic information system (GIS) and multi-criteria method (Aburas et al., 2017). This study finds out the existing parking patterns of e-taxi on the road for passenger load and unloads which consequences traffic congestion and finds out the points where this parking occurs. To solve the problem, it is very urgent to establish an e-taxi station at the Pabna Municipality area. This e-taxi stand obviously should be established in such a place where land acquisition will be easy as well as in a computing distance from the points where most load and unload of passenger happens. Another thing has to keep in mind that the station should have easy access to the road. By considering these criteria this study finds out a suitable place for constructing an e-taxi stand. This study will help to reduce the traffic congestion caused by 
e-taxi and will make sure a smooth traffic system. Another thing is that it will reduce the risk of accidents which happen frequently due to the parking of e-taxi on-road and mainly at the time of load and unload of passengers. These e-taxi drivers unload passengers on the road which consequences frequent accidents in the municipality area. Another important side of the study is that this study will help the policymakers to solve the e-taxi parking problem and also solve the traffic congestion caused by e-taxi permanently.

\section{Literature Review}

Nemours work has been done on traffic management and traffic flow analysis on Pabna. To identify the points where e-taxi are parked on the road and the pattern of the parking as well as the e-taxi parking effect of on the level of service (LOS) some studies on the Pabna transportation system are being studied. (Chakma et al., 2018) analyze the e-taxi present situation and impact on the LOS of the roads of the Pabna Municipality area. This study also finds out the causes of increasing the number of illegal e-taxi. The present parking facilities of Pabna municipality along with the demand and supply is being analyzed at (Rahman et al., 2017). This study helps to identify the parking scenario of e-taxi and other automobiles the existing Pabna Municipality road network. (Hossain and Hasan, 2019) studies the current traffic flow characteristics and traffic congestion which helps this study to find out the reasons for traffic jams at Pabna Municipality. Besides these studies (Zhu et al., 2020) helps to understand the impact of parking on the traffic flow and travel time. For the suitable spot assessment of e-taxi station, some paper is also studied which helps to determine the criteria for the study and also to find out an appropriate method (Parry et al., 2018; Zabihi et al., 2019; Njiru and Siriba, 2018). Almost all of these study usage dissimilar criteria for the analysis of suitability assessment but these studies also have cast-off the opinion of the experts for degerming criteria and weight.

Saaty (1990) introduces the AHP method which is very much acceptable for site suitability analysis for any development project. This study helps to understand the AHP and hierarchy model properly. Parvez and Islam (2020) helps to understand the AHP method properly and also helps to determine the criteria as this study was conducted on Pabna Municipality. The study of Madurika and Hemakumara (2017) helps to understand how a study can be conducted to develop a development project to resolve a problem likely in this study. Dinda et al. (2018) shows how transportation and the AHP method can be integrated and successful use of the AHP method can be implemented on the transportation problem solution. Another study that helps to integrated AHP and transportation systems scientifically is conducted by resolving different problems regarding transport where the finest choice has to be resolute typically in several selected quantitative standards (Podvezko et al., 2014). A review paper on Suitability and Selection of Station Rail Transit helps to understand the importance of the hierarchy process for constructing a station that will help to solve a public problem (Akabal et al., 2017).

\section{Materials and methods}

\subsection{Study area profile}

In the year 1874, the Pabna Municipality was established and it is one of the primogenital Municipality of Bangladesh. The total calculated area of the Pabna Municipality is 15.66 Sq.km and the population density is 8130/sq.km. Absolute Geographical location of Pabna Municipality is $23^{\circ} 53^{\prime \prime} \mathrm{N}$ and $24^{\circ} 05^{\prime \prime} \mathrm{N}$ latitude and $89^{\circ}$ $09^{\prime} \mathrm{E}$ and $89^{\circ} 25^{\prime \prime} \mathrm{E}$ longitudes. It is located at $161 \mathrm{~km}$ Northwest of Capital city and $110 \mathrm{~km}$ East of the city of Rajshahi (Parvez and Islam, 2020). Transportation land use has been estimated from the total area under road, bus terminal, truck terminal, and 
SRT

2,2

58

BRTC bus depot. The total land under this use has been found 264.495 acres $(6.85 \%)$. There are three types of roads like primary, secondary, and tertiary roads found in the Pabna Municipality area. The Pabna Municipality area is served by $142.86 \mathrm{~km}$ of road. About $75 \%$ of the road system has a surface made of bitumen. Non-motorized transport (rickshaw, van, bicycle and, e-taxi). dominates the traffic scene in the Pabna Municipality where the percentage of rickshaws and e-taxi varies between 70 to $91 \%$ of the traffic and where $90 \%$ of all retail and wholesale foodstuff are moved by rickshaws and e-taxi (MIDP, 2008) (Figure 1).

\subsection{Methodology}

For the study, both primary and secondary data were collected. Primary data on existing parking points on the road of e-taxi which consequences traffic congestion are collected from the Municipality area. Secondary data on the existing road network of the Pabna Municipality has collected from the MIDP data also from the literature review. For the suitability analysis process for establishing an e-taxi station, six variables were determined. These variables are determined from the previous studies and the expert opinion survey. The six variables are Land use of the study area, Road network of the study area, Proximity to the office area, Proximity to the educational facilities, proximity from the market, and finally proximity from the Hospital. After the selection of the variables ranking value was determined from the expert opinion. Then using The AHP method final weight value is determined and finally, with the assist of GIS, the suitability map was created from which the suitable space for the e-taxi stand was found. To decide a prepared way to generate priorities we need to make comparisons and want a scale of

Figure 1. Location map of the study area

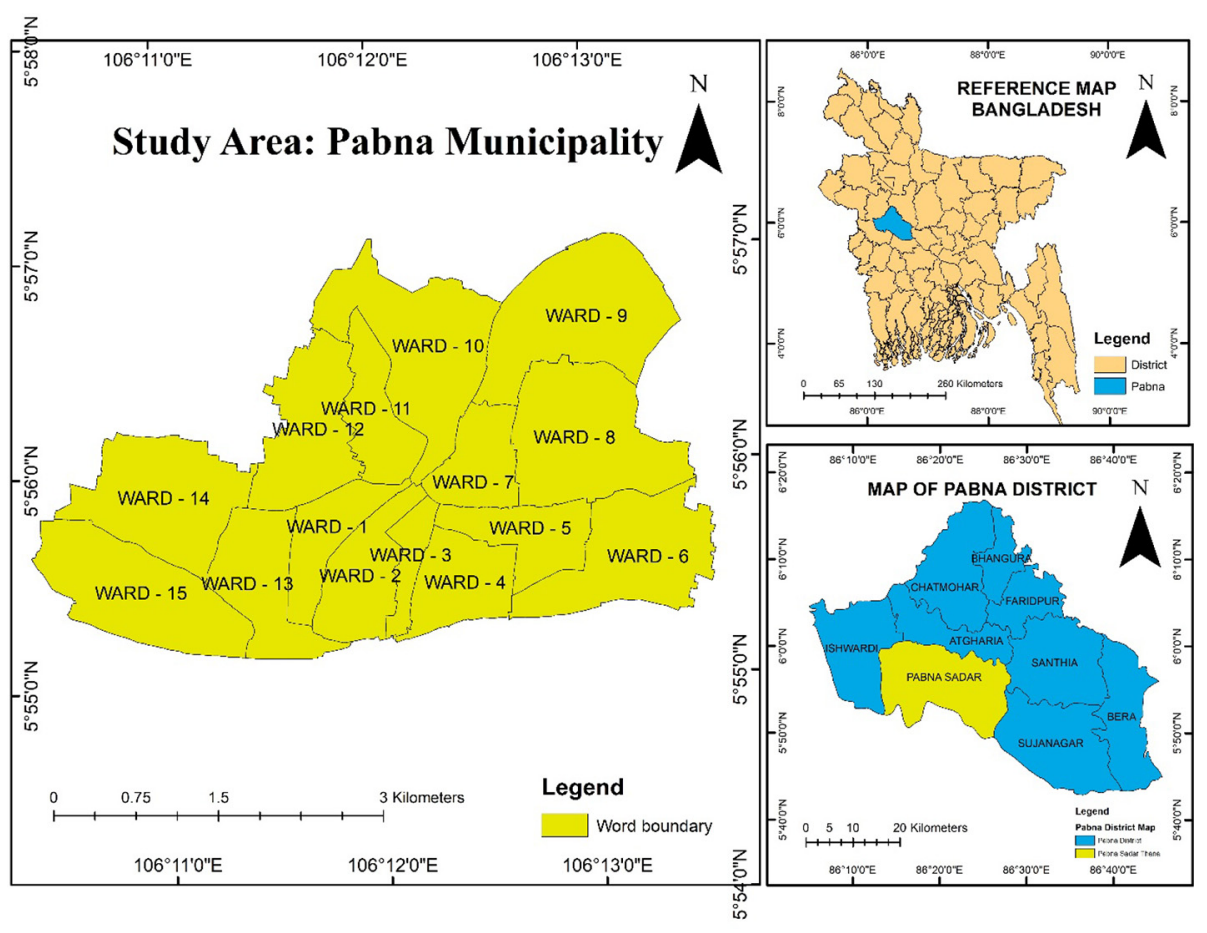


numbers that suggests how typically more crucial or dominant one detail is over some other element concerning the criterion or property they're in comparison. The AHP is a principle of size thru pairwise comparison. The comparisons are made the use of a scale of absolute judgments that represents how an awful lot greater; one detail dominates every other regarding a given characteristic. The derived priority scales are synthesized through multiplying them via the concern of their parent nodes and including for all such nodes (Parry et al., 2018) (Table 1).

\subsection{Consistency ratio calculation}

A Mathematical index called Consistent Ratio (CR) is used to assess the constancy of the pair-wise comparison matrix:

$$
\mathrm{CR}=\frac{C I}{R I}
$$

The calculation of $\mathrm{CI}$ is given as:

$$
\mathrm{CI}=\frac{(\lambda \max -\mathrm{n}) /(\mathrm{n}-1)}{R I}
$$

where, $\lambda$ max implies the supreme value, and the quantity of impacts is articulated by $n$, while the mean average consistency index $(\mathrm{CI})$ is signified by RI. The suitability of the AHP and higher consistency results as signified by the relevant index should be inferior to 0.10 (Zabihi et al., 2019).

The RI cast-off to pivot on the sum of the values (Njiru and Siriba, 2018). Here the total number of variables is 6 that means $n=6$. From (Table 2 ) the value is determined as $R I=1.24$.

\section{Intensifying the present parking problem and impact regarding e-taxi}

Neither in the Dhaka, now this problem of e-taxi and rickshaw scattering up into the municipality level as well. E-taxi and rickshaw are measured as the key reasons for this traffic overcrowding and the cause is that the slow-movement of vehicles and parking of roadside happens. And it also causes overlooking traffic guidelines and rules (Rahim et al., 2012; Rahman et al., 2004). The amount of e-taxi is growing quickly in the municipal parts

\begin{tabular}{llr}
\hline Importance of order & Suitability rank & Numerical appearance \\
\hline Equal significance & Very little suitable & 1 \\
Modest significance of one over another & partly suitable & 3 \\
Key or sturdy significance & Moderately suitable & 5 \\
Very strong significance & Mostly suitable & 7 \\
Supreme significance & Optimally suitable & 9 \\
& Intermediate values & $2,4,6,8$
\end{tabular}

Source: Zabihi et al. (2019)
Geo-spatial and AHP approaches 
SRT

2,2

60

and rising city hearts in Bangladesh and the automobile has become the most leading city transportation mode in the parts of municipalities (Mamun, 2015). These e-taxies are primarily familiarized in the municipality of Pabna by some fervent commercial companies. Around $80 \%$ of city folks use the low-cost taxis to travel to certain portions of the town (Chakma, 2018). The peak hour for Pabna Municipality id 11:30- 12:30 PM and 4:00-5:00 PM (Rahman et al., 2017). At that particular time, from (Table 3) it is seen e-taxi demands 4234 square feet of area per at the working day only at the CBD area. The quantity if the vehicle at the working day is 146 which is the largest among the three and two-wheeler of transport (e.g. Rickshaw, Van, or motorcycle). At the holiday the quantity number is 88 and it requires 2553 square feet. One thing is to remember that these required parking spaces cannot be fulfilled by the Pabna Municipality Authority. As a result, this e-taxi are parked on the road consequences traffic jam. The furthermost receptive harmful feature of the e-taxi action is the traffic overcrowding (45.6\%) in the (CBD) area. It is quite hard to passage 5000 unlicensed e-taxis on only $187.50 \mathrm{~km}$ road among it almost $18.80 \mathrm{~km}$ streets unpaved (Chakma et al., 2018).

A survey was conducted to identify the points where e-taxi are parked on the road. Figure 2 shows those points where the parking happened. At the CBD area mainly at the word no 2 and there are several points. Indira More points, Traffic more points, Newmarket point, Robiul Market point, Point Infront of Town Hall, Central Girls School point, Alia Madrasa point, and Poilanpur Point. Besides the town, there are numerous places where this e-taxi is parked. Mainly at the CBD area, the e-taxi are parked for loading and unloading of passengers as most of the office and retail markets are situated in the CBD area. Besides shopping malls, restaurants, Cinema Hall, private clinics and, repeated educational institutes are here. Adward college more is important because more than several thousand students study their consequences this parking, Meril Bypass is an important point where the auto is parked as the Square Pharmaceuticals and Industry is there. So, a lot of works make a trip there. In front of Police Station and Government hospital, this parking happens because a lot of Municipality dwellers everyday make trips for taking service from these places. There is only one Bus Terminal at Pabna. As a result, every day from different places outside of Pabna Municipality people come to Pabna. From the Terminal people have to make a trip to the other section of the Municipality. That is why a lot of e-taxi are parked for load and unloading of passengers. Hazir hat point is another important point. At this point the retail market is present and weekly two days this market becomes full of people so that lot of parking happens here. Gaspara point is the entry point to the Pabna Municipality

Table 3.

Pabna municipality CBD demand for parking in respect of the number of vehicles

\begin{tabular}{lcccc}
\hline & $\begin{array}{c}\text { Quantity of } \\
\text { vehicle at } \\
\text { working day }\end{array}$ & $\begin{array}{c}\text { Required space } \\
\text { (Sq. Ft) }\end{array}$ & $\begin{array}{c}\text { Quantity of vehicle } \\
\text { at public holiday }\end{array}$ & $\begin{array}{c}\text { Required Space } \\
\text { (Sq. Ft) }\end{array}$ \\
Automobile type & 106 & 4134 & 107 & 4173 \\
\hline Rickshaw & 28 & 6916 & 30 & 7410 \\
Car & 72 & 22104 & 30 & 9210 \\
Micro/ Pickup & 11 & 4279 & 22 & 8558 \\
Bus/ Truck & 146 & 4234 & 88 & 2552 \\
E-taxi & 56 & 1624 & 33 & 957 \\
Van & 106 & 530 & 52 & 260 \\
Motorcycle & 525 & 43821 & 362 & 33120 \\
Total & & & & \\
Source: Rahman et al. (2017) & & & &
\end{tabular}




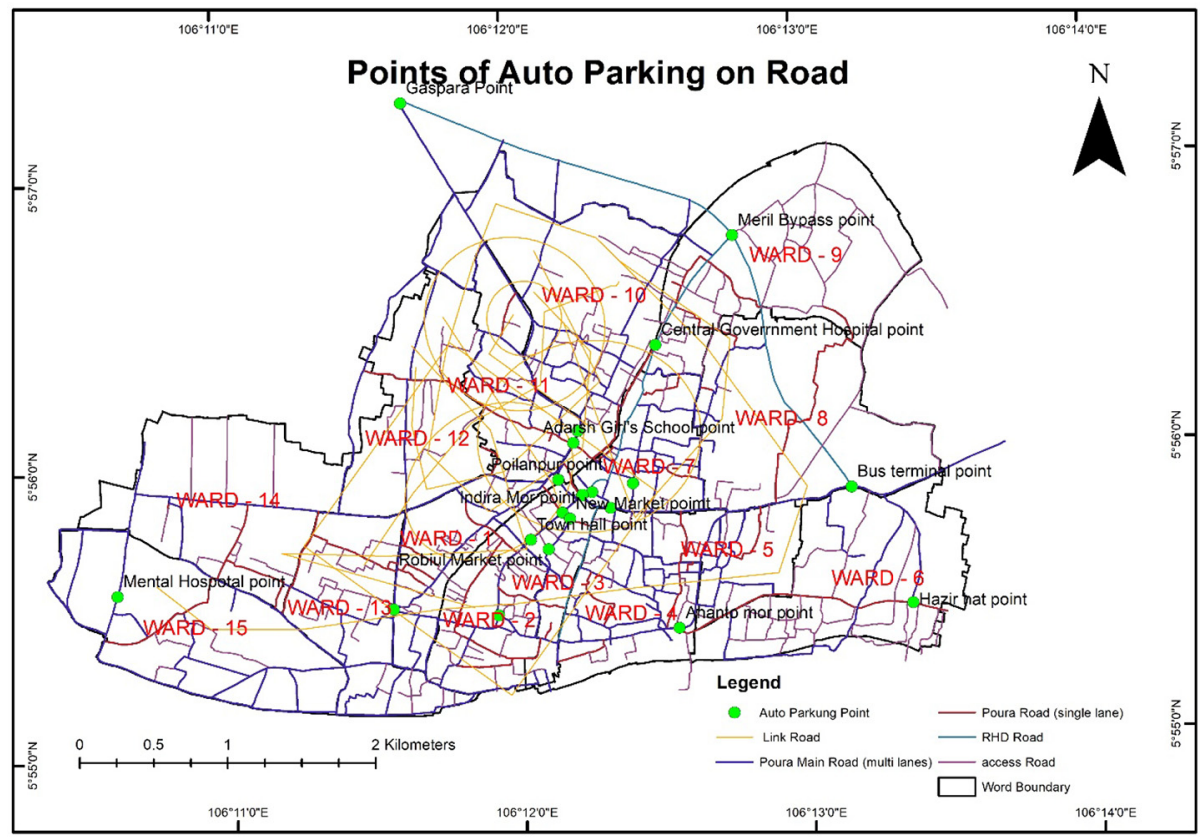

Source: Author (2020)
Geo-spatial and AHP approaches

61
Figure 2.

Points of auto parking on road

so a lot of commercial activities happen here consequences e-taxi parking. Mental Hospital is a famous institution of Pabna as well as in Bangladesh. Every day from each corner of Bangladesh patients come for treatment here also the municipality dwellers come to visit this place as it is a very attractive place to visit. For this e-taxi are parked here. From the survey of Traffic volume, it is revealed that the e-taxi was very much dynamic in the Pabna municipality area and harm the LOS of the road. LOS trials the working circumstances of a street constructed on travel time, speed, maneuverability, and safety. LOS is selected with a letter, A to $\mathrm{F}$, where " $\mathrm{A}$ " stands the finest-operating circumstances and " $\mathrm{F}$ " the stands for the worst one (Kadiyali, 2013) (Figure 2).

From the traffic volume survey conducted by the author, the impact of the LOS by e-taxi is determined. Using (Table 4) the LOS. Volume and Capacity are determined from field surveys.

From terminal to CBD, the number of vehicles (PCU, V) is 4,595, capacity (c) is 5,928, Peak hour $(\mathrm{V} / \mathrm{C})$ is found 0.77 , Carriageway is $7 \mathrm{~m}$. So, from terminal to CBD, the LOS is D. On the other hand, From CBD to terminal, the number of vehicles (PCU, V) is 4,176, capacity (c) is 3,601, Peak hour $(\mathrm{V} / \mathrm{C})$ is found 1.16 , Carriageway is $6.5 \mathrm{~m}$. So, from CBD to Terminal, the LOS is F. Then, From CBD to Meril Bypass, the number of vehicles (PCU, V) is 3,298, capacity (c) is 5,928, Peak hour (V/C) is found 0.55, Carriageway is $8.5 \mathrm{~m}$. So, from CBD to Terminal, the LOS is C. Moreover, From CBD to Ananto Mor, the number of vehicles (PCU, V) is 2,720, capacity (c) is 3,600, Peak hour (V/C) is found 0.75 , Carriageway is $8 \mathrm{~m}$. So, the LOS is D. From CBD to Adward College, the number of vehicles (PCU, V) is 2,040, capacity (c) is 3,025, Peak hour (V/C) is found 0.68 , Carriageway is $6.8 \mathrm{~m}$. So, the LOS is C. From CBD to Adward College, the number of 
SRT

2,2

62

vehicles (PCU, V) is 2,040, capacity (c) is 3,025, Peak hour (V/C) is found 0.68, Carriageway is $6.8 \mathrm{~m}$. So, the (LOS) is C. From CBD to Library Bazar, the number of vehicles (PCU, V) is 1,728, capacity (c) is 3,600, Peak hour (V/C) is found 0.48 , Carriageway is 8 . So, the LOS is B. Again, from Meril Bypass to CBD, the number of vehicles (PCU, V) is 2,895, capacity (c) is 3,989, Peak hour (V/C) is found 0.72 , Carriageway is $7 \mathrm{~m}$. So, from Meril Bypass to CBD, the LOS is D. From Gaspara to Bus Terminal the number of vehicles (PCU, V) is 1,748 , capacity (c) is 3,575 , Peak hour (V/C) is found 0.48, Carriageway is $9 \mathrm{~m}$. So, the LOS is B. Figure 3 visualizes the present impact of e-taxi on the level of service on road.

\section{Weighted index analysis}

Medians of pairwise checks are designed both with the resource of offering verdicts to approximation ascendancy using absolute numbers from the 1 to 9 critical scale of the AHP or employing at once production the pairwise dominance ratios using actual extents (Saaty, 2007).

All criteria the usage of the fundamental scale is carried out with the pairwise evaluation proven in (Table 5), which was proposed as part of AHP. The depth of significance is assigned to standards $i$ whilst associated with criteria $j$ and the joint fee is allotted to criteria $\mathrm{j}$ as the order of rank. Whilst contrast among all viable standards pairs are finished, a load of standards $i$, which is used in later analysis for suitability analysis, is calculated using equation (3).

$$
\text { wi } \sum_{i=1}^{n} \mathrm{Pij} / \sum_{i=1}^{n} o \sum_{i=1}^{n} \mathrm{P} i j
$$

where, labels relative rank in a pairwise comparison of standards $i$ relating to value $\mathrm{j}$ (Dai, 2016).

$$
\begin{aligned}
\lambda_{\max }= & (2.11 \times 0.408)+(11.190 .167)+(11.45 \times 0.236))+(16.53 \times 0.106)+(23.33 \times 0.059) \\
& +(18 \times 0.049)=9.15621
\end{aligned}
$$

$$
\begin{aligned}
& \mathrm{CR}=\frac{(\lambda \max -n)}{(\mathrm{n}-1)}=\frac{9.15621-6}{5}=0.6312 \\
& \mathrm{CR}=\frac{C I}{R I}=\frac{0.6312}{1.24}=0.509<\text { (acceptable) }
\end{aligned}
$$

Six criteria were undertaken. Under land use, Vacant land and water body (e.g. pond) is undertaken as these types of land are easy to undertake for a development project. The road of Municipality data was taken from the MIDP data. Data on Office, Hospital, Educational

Table 4.

\begin{tabular}{lc}
\hline LOS & V/C ratio \\
\hline A & $0.00-0.35$ \\
B & $0.35-0.58$ \\
C & $0.58-0.75$ \\
D & $0.75-0.90$ \\
E & $0.90-1.00$ \\
F & $>1.00$ \\
Source: Kafy et al. (2018) & \\
\hline
\end{tabular}




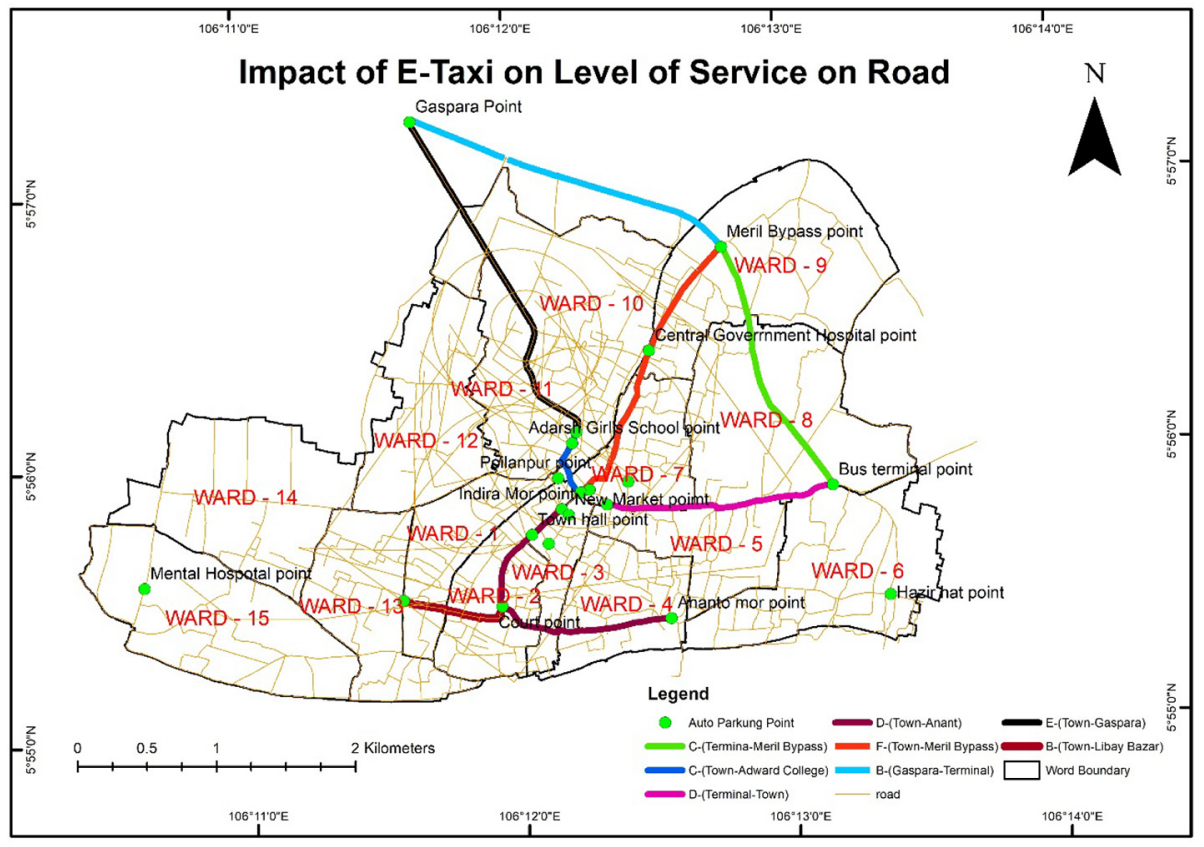

Source: Author (2020)
Geo-spatial and AHP approaches

63

Figure 3. Impact of e-taxi on level of service on road

facilities, Hospital, and Market is also taken from MIDP data and then digitize into GIS. From a previous study, the trip generation data was taken and analyzed. About $15 \%$ of etaxi trips are made for education purposes; $4 \%$ Hospital visit; for shopping purposes $9 \%$; for others and personal work $3 \%$ was made; and the other $69 \%$ trips are made for office work (Chakma et al., 2018). So, this trip generation study as well as the expert opinion survey helps to determine the weighted index value. CI value is less than 1 . That means the criteria are acceptable. Tables 5 and 6 show the weighted value and Pairwise comparison matrix. After calculating both of them the $\lambda$ max value by multiplying every category value of the

\begin{tabular}{|c|c|c|c|c|c|c|}
\hline Criteria of suitability & $\begin{array}{l}\text { Vacant } \\
\text { land }\end{array}$ & $\begin{array}{c}\text { Proximity to } \\
\text { office }\end{array}$ & Road & $\begin{array}{l}\text { Proximity to } \\
\text { educational } \\
\text { institutions }\end{array}$ & $\begin{array}{l}\text { Proximity } \\
\text { to hospital }\end{array}$ & $\begin{array}{c}\text { Proximity to } \\
\text { market }\end{array}$ \\
\hline Land use & 1 & 9 & 7 & 3 & 5 & 3 \\
\hline Proximity to office & 0.11 & 1 & 3 & 5 & 3 & 3 \\
\hline Road & 0.14 & 0.33 & 1 & 7 & 9 & 5 \\
\hline $\begin{array}{l}\text { Proximity to educational } \\
\text { institutions }\end{array}$ & 0.33 & 0.2 & 0.14 & 1 & 5 & 3 \\
\hline Proximity to hospital & 0.2 & 0.33 & 0.11 & 0.2 & 1 & 3 \\
\hline Proximity to market & 0.33 & 0.33 & 0.2 & 0.33 & 0.33 & 1 \\
\hline Sum & 2.11 & 11.19 & 11.45 & 16.53 & 23.33 & 18 \\
\hline
\end{tabular}

Source: Author (2020)

Table 5. Weighted index matrix 
SRT

2,2

64

sum of each criterion and the weight of each criterion. After that, all the sum of the values is calculated. After that CI value is calculated.

\section{Result and discussion}

From the pair-wise comparison matrix, the AHP weighted per cent is determined (Table 7). As for the construction of an e-taxi station, the land is the most important criteria as the station cannot be established on someone's private property or office land.

So that the vacant and waterbody is used for the most significant criteria. $500 \mathrm{~m}$ buffer was constructed around the land. Five criteria were determined. For land beside $100 \mathrm{~m}$ buffer the optimally suitable place was determined, $200 \mathrm{~m}$ as most suitable, 300 as moderate suitable, $400 \mathrm{~m}$ as partly suitable and finally 500 the very little suitable. For the criteria of road $25 \mathrm{~m}$ buffer was created. $5 \mathrm{~m}$ beside the road is optimally suitable and 25 is very little suitable. Meanwhile, an equal interval with $5 \mathrm{~m}$ was maintained for the road with like land use. For the office, educational facilities, health facilities, and market facilities $200 \mathrm{~m}$ buffer were created with an equal interval of $50 \mathrm{~m}$ from optimally suitable to very little suitable. After calculating the Euclidian distance and making reclass of them the weighted overlay operation was made. After that, the final suitability map for the propped e-taxi station was created. Form the resulting total 4,285 spots were found as optimally suitable spots are found which is almost $21 \%$ of the suitable spot. No mostly suitable spots are found from the GIS analysis. The moderately suitable spots were found in the prime number of 14,817 spots, almost $75 \%$ of the suitable spot. Likely the most suitable spots no partly suitable spots were found but the number of very few suitable spots was found in the number of 918 ,

Table 6.

Assessment of pairwise matrixes for calculated values weights

\begin{tabular}{|c|c|c|c|c|c|c|c|}
\hline Criteria of suitability & $\begin{array}{l}\text { Land } \\
\text { use }\end{array}$ & $\begin{array}{l}\text { Proximity to } \\
\text { office }\end{array}$ & Road & $\begin{array}{l}\text { Proximity to } \\
\text { educational } \\
\text { institutions }\end{array}$ & $\begin{array}{l}\text { Proximity to } \\
\text { hospital }\end{array}$ & $\begin{array}{l}\text { Proximity to } \\
\text { market }\end{array}$ & Weight \\
\hline Land use & .473 & 0.805 & 0.611 & 0.181 & 0.215 & 0.167 & 0.408 \\
\hline Proximity to office & 0.053 & 0.089 & 0.262 & 0.303 & 0.128 & 0.167 & 0.167 \\
\hline Road & 0.067 & 0.029 & 0.088 & 0.423 & 0.386 & 0.277 & 0.211 \\
\hline $\begin{array}{l}\text { Proximity to educational } \\
\text { institutions }\end{array}$ & 0.157 & 0.018 & 0.013 & 0.061 & 0.214 & 0.167 & 0.106 \\
\hline Proximity to hospital & 0.094 & 0.029 & 0.009 & 0.013 & 0.043 & 0.167 & 0.059 \\
\hline Proximity to market & 0.156 & 0.029 & 0.017 & 0.019 & 0.014 & 0.055 & 0.049 \\
\hline Sum & & 1 & & 1 & 1 & & \\
\hline
\end{tabular}

Source: Author (2020)

Criteria of suitability

AHP weight impact (\%)

Table 7.

Final weight impact percentage
Land use

Proximity to office

Road

Proximity to educational institutions

Proximity to hospital

Proximity to market

41

17

22

10

5

Source: Author (2020) 
$4 \%$ of the suitable spot. A total of 20,020 spots was found as suitable for the construction of E-taxi station (Figures 4 and 5).

\section{Conclusion}

The study is aiming to solve the current traffic congestion problem caused by e-taxi parking on the road. To solve the problem this study identifies several points from the literature review and the field survey. Moreover, the present impact of e-taxi on the level of service of

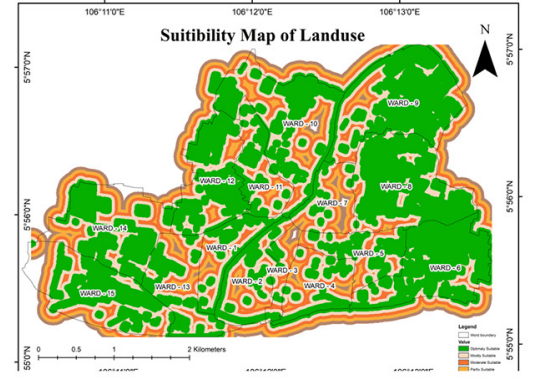

(a)

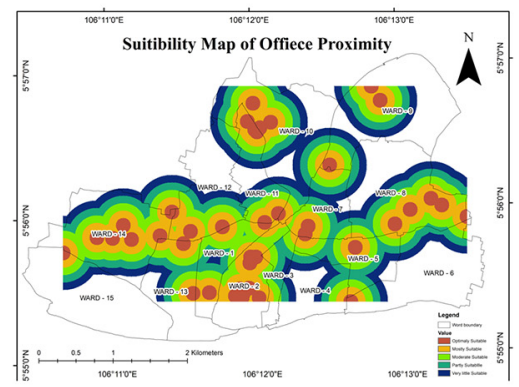

(c)

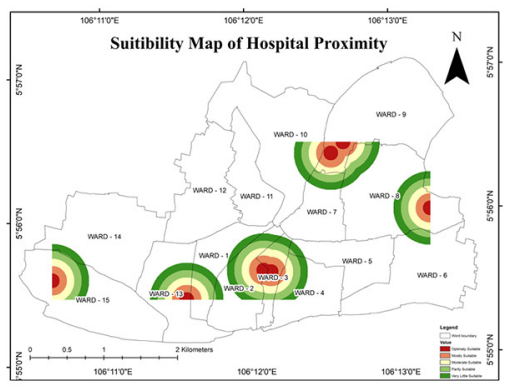

(e)

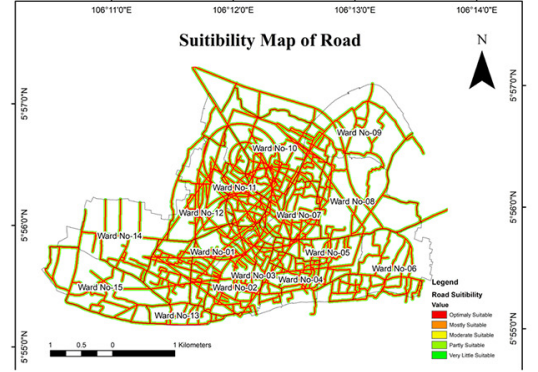

(b)

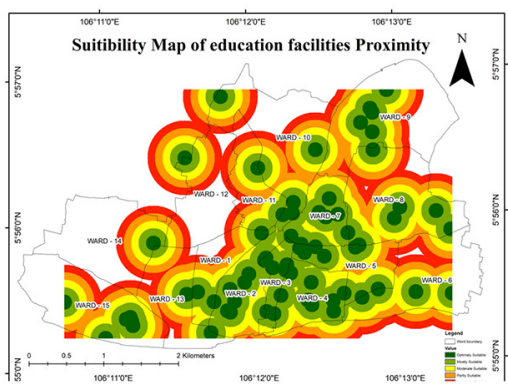

(d)

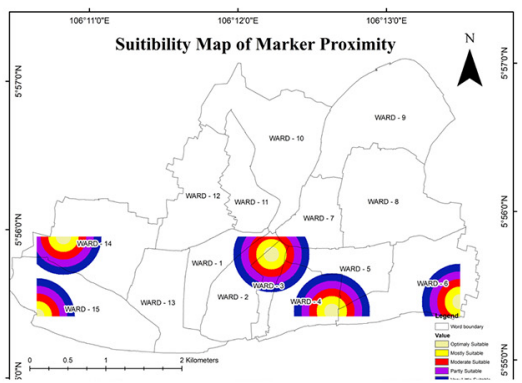

(f)
Geo-spatial and AHP approaches 


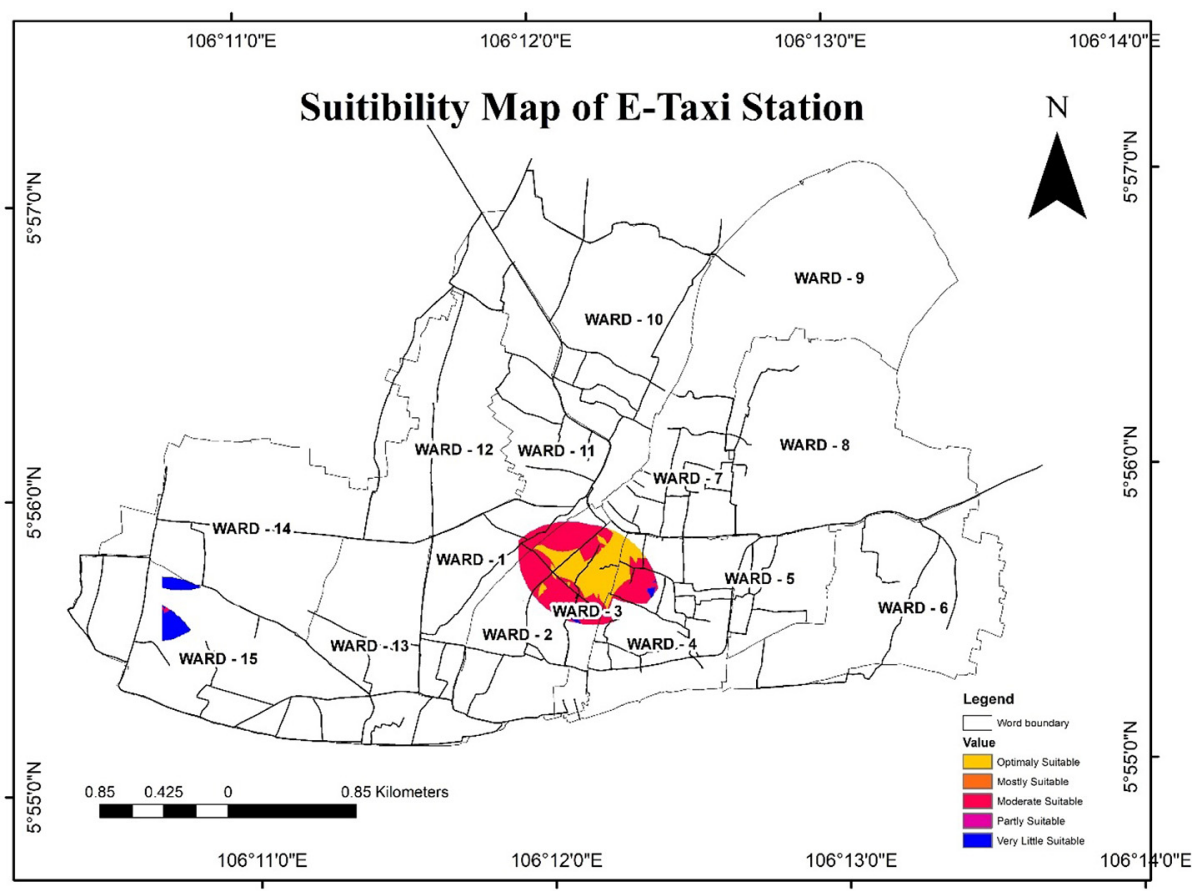

the road is identified from the field survey. To resolve the problem six criteria were identified from the expert opinion survey and the literature review. After that weighted index matrix and using AHP the optimal site for the e-taxi station was identify. From the field survey, it is seen that mainly at the CBD area at a word no. 2, 3 and 7 the e-taxi parking happened. The optimal suitable location is finding very close to these spots. That means if this e-taxi station builds, then people can have very easy access to the e-taxi station as well as the parking on road can be avoided. By this, a permanent solution to traffic congestion at the Pabna Municipality area can be resolved.

\section{References}

Aburas, M.M., Abdullah, S.H.O., Ramli, M.F. and Asha'ari, Z.H. (2017), "Land suitability analysis of urban growth in Seremban Malaysia, using GIS-based analytical hierarchy process", Procedia Engineering, Vol. 198 No. 6, pp. 1128-1136, doi: 10.1016/j.proeng.2017.07.155.

Akabal, F.M., Mohd Masirin, M.I.H., Akasah, Z.A. and Rohani, M.M. (2017), "Review on selection and suitability of rail transit station design pertaining to public safety", IOP Conference Series: Materials Science and Engineering, Vol. 226, doi: 10.1088/1757-899x/226/1/012033.

Al-Shabeeb, A.R. (2016), "The use of AHP within GIS in selecting potential sites for water harvesting sites in the Azraq Basin - Jordan”, Journal of Geographic Information System, Vol. 08 No. 1, pp. 73-88, doi: 10.4236/jgis.2016.81008.

Banu, M. and Rahman, M. (2016), "Demand and supply of parking facility and the effects of on-street parking on roadway capacity", $3 r d$ International Conference on Advances in Civil Engineering, CUET, Chittagong, Bangladesh. 
Cao, Y., Yang, Z.Z. and Zuo, Z.Y. (2016), "The effect of curb parking on road capacity and traffic safety", European Transport Research Review, Vol. 9 No. 1, doi: 10.1007/s12544-016-0219-3.

Chakma, M. (2018), "Analyze the effect of drivers behaviors and socioeconomic condition on traffic flow: a case study of Pabna municipality, Bangladesh", Proceeding in the 4th International Conference on Civil Engineering for Sustainable Development (ICCESD 2018), KUET, Khulna, Bangladesh. ISBN: 978-984-34-3502-6, pp.261-262.

Chakma, M., Rana, M.S. and Pramanik, M.A. (2018), "Prediction and analysis of the causes of increasing an illegal e-taxi in Bangladesh municipalities", International Journal of Crowd Science, Vol. 2 No. 3, pp. 178-197, doi: 10.1108/ijcs-06-2018-0010.

Dai, X. (2016), Dam Site Selection Using an Integrated Method of AHP and GIS for Decision Making Support in Bortala, Lund University, Lund.

Dinda, S., Ghosh, S. and Das Chatterjee, N. (2018), "An analysis of transport suitability, modal choice, and trip pattern using accessibility and network approach: a study of Jamshedpur city", Spatial Information Research, Vol. 27 No. 2, pp. 169-186, doi: 10.1007/s41324-018-0223-x.

Fukumoto, M., Matsuo, K. and Matsumoto, Y. (2017), "A study into the factors affecting the number of taxi trips in Toyohashi, Japan", Journal of the Eastern Asia Society for Transportation Studies, Vol. 12 (2017, pp. 1434-1447, doi: 10.11175/easts.12.1434.

Hossain, M.T. and Hasan, K.M. (2019), "Assessment of traffic congestion by traffic flow analysis in Pabna town", American Journal of Traffic and Transportation Engineering, Vol. 4 No. 3, p. 75, doi: 10.11648/j.ajtte.20190403.11.

Kadiyali, L.R. (2013), Traffic Engineering and Transport Planning, Khanna Publishers, Delhi, India.

Kafy, A.A., Ferdous, L., Poly, S.A., Arafat, M., Monira, S., Rahman, M.S., Rahman, N., Afroz, F., Mahzabin, F., Ahmed, T., Khan, N.A., Mohiuddin, H. and Hossaim, N. (2018), "Estimating traffic volume to identify the level of service in major intersections of Rajshahi", Bangladesh. Trends in Civil Engineering and Its Architecture, Vol. 2 No. 4, doi: 10.32474/tceia.2018.02.000145.

Khahro, S.H., Matori, A.N., Chandio, I.A. and Talpur, M.A.H. (2014), "Land suitability analysis for installing new petrol filling stations using GIS", Procedia Engineering, Vol. 77, pp. 28-36, doi: 10.1016/j.proeng.2014.07.024.

Madurika, H.K.G.M. and Hemakumara, G.P.T.S. (2017), "GIS-Based analysis for suitability location finding in the residential development areas of Greater Matara region", International Journal of Scientific and Technology Research, Vol. 6, pp. 96-105.

Mamun, A.H. (2015), "Electric three wheelers and municipal transportation in Bangladesh", International Journal of Innovative and Applied Research, Vol. 3 No. 2, pp. 12-16.

MIDP (2008), Municipality Infrastructure Development Plan, Pabna.

Njiru, F.M. and Siriba, D.N. (2018), "Site selection for an earth dam in Mbeere North, Embu County-Kenya", Journal of Geoscience and Environment Protection, Vol. 06 No. 7, pp. 113-133, doi: 10.4236/gep.2018.67009.

Parry, J.A., Showkat, A.G. and Bhat, M.S. (2018), "GIS based land suitability analysis using the AHP model for urban services planning in Srinagar and Jammu urban centers of Jandk, India", Journal of Urban Management, Vol. 7 No. 2, pp. 46-56, doi: 10.1016/j.jum.2018.05.002.

Parvez, M. and Islam, S. (2020), "Sites suitability analysis of potential urban growth in Pabna municipality area in Bangladesh: AHP and geospatial approaches", Journal of Geographical Studies, Vol. 3 No. 2, pp. 82-92, doi: 10.21523/gcj5.19030204.

Podvezko, V., Sivilevicius, H. and Podviezko, A. (2014), "Scientific applications of the AHP method in transport problems", Archives of Transport, Vol. 29 No. 1, pp. 47-54, doi: 10.5604/08669546.1146966.

Rahim, M.A., Joardder, M.U.H., Hoque, S.M.N., Rahman, M.M. and Sumon, N.H. (2012), "Socio-economic and environmental impacts of a battery-driven auto-rickshaw at Rajshahi city in Bangladesh", International Conference on Mechanical, Industrial and Energy Engineering 2012 01-02 February 2013, Khulna, Bangladesh. 
SRT

2,2

68

Rahman, A., Prothan, J.I.J., Islam, M. and Pramanik, A. (2017), "Parking provision for CBD area of Pabna town in Bangladesh", European Journal of Engineering Research and Science, Vol. 2 No. 9, p. 27, doi: 10.24018/ejers.2017.2.9.453.

Rahman, M.M., Okura, I. and Nakamura, F. (2004), "Effects of rickshaws and auto-rickshaws on the capacity of urban signalized intersections", IATSS Research, Vol. 28 No. 1, pp. 26-33, doi: 10.1016/s0386-1112(14)60089-3.

Saaty, T.L. (1980), The Analytical Hierarchy Process, McGraw-Hill, New York, NY.

Saaty, T.L. (1990), "How to make a decision: the analytic hierarchy process", European Journal of Operational Research, Vol. 48 No. 1, pp. 9-26, doi: 10.1016/0377-2217(90)90057-I.

Saaty, T.L. (2007), "Time-dependent decision-making; dynamic priorities in the AHP/ANP: generalizing from points to functions and from real to complex variables", Mathematical and Computer Modelling, Vol. 46, pp. 860-891, doi: 10.1016/j.mcm.2007.03.028.

Subramani, T. (2012), "Pedestrian study on road links in the major urban center", IOSR Journal of Engineering, Vol. 02 No. 4, pp. 750-754, doi: 10.9790/3021-0204750754.

Zabihi, H., Alizadeh, M., Kibet Langat, P., Karami, M., Shahabi, H., Ahmad, A., Nor Said, M. and Lee, S. (2019), "GIS multi-criteria analysis by ordered weighted averaging (OWA): toward an integrated citrus management strategy", Sustainability, Vol. 11 No. 4, p. 1009, doi: 10.3390/su11041009.

Zhu, Y., Ye, X., Chen, J., Yan, X. and Wang, T. (2020), "Impact of cruising for parking on”, Sustainability, Vol. 12 No. 8, p. 3079, doi: 10.3390/su12083079.

\section{Corresponding author}

Mazed Parvez can be contacted at: parvezpust30@gmail.com

For instructions on how to order reprints of this article, please visit our website: 